\title{
ESTABELECIMENTO DO ARROZ IRRIGADO E ABSORÇÃO DE CÁTIONS EM FUNÇÃO DO MANEJO DA ADUBAÇÃO POTÁSSICA E DO NÍVEL DE SALINIDADE NO SOLO ${ }^{(1)}$
}

\author{
Felipe de Campos Carmona ${ }^{(2)}$, Ibanor Anghinoni ${ }^{(3)}$, Egon José Meurer ${ }^{(4)}$, \\ Marquel Jonas Holzschuh ${ }^{(5)}$ \& Thiago Isquierdo Fraga ${ }^{(6)}$
}

\begin{abstract}
RESUMO
O uso da água para a irrigação do arroz no Rio Grande do Sul, cujos mananciais hídricos têm ligação com o mar, pode ocasionar acúmulo de sais no solo em concentrações prejudiciais ao estabelecimento da cultura nos anos subsequentes, especialmente quando são aplicadas altas doses de fertilizante potássico na linha de semeadura. Este trabalho foi realizado com o objetivo de avaliar o efeito do manejo da adubação potássica sobre o estabelecimento e a absorção de cátions pelo arroz (cultivar IRGA 417) em um solo com diferentes níveis de saturação por Na. Foram utilizados um Planossolo Háplico com saturações por Na na troca de 5, 10 e $20 \%$; três manejos da adubação com cloreto de $\mathrm{K}$ equivalentes a $120 \mathrm{~kg} \mathrm{ha}^{-1} \mathrm{de}$ $\mathrm{K}_{2} \mathrm{O}$ a lanço; $120 \mathrm{~kg} \mathrm{ha}^{-1}$ de $\mathrm{K}_{2} \mathrm{O}$ na linha de semeadura e $60 \mathrm{~kg} \mathrm{ha}^{-1} \mathrm{de}_{2} \mathrm{O}$ na linha de semeadura, além de uma testemunha, sem adição de sal e de fertilizante, fatorial (3 x 3) + 1. O estande de plântulas não foi afetado pelos níveis de salinidade do solo e manejo da adubação potássica. A ontogenia da planta foi afetada pela salinidade, com atraso na emergência das plântulas. A salinidade do solo, a partir de $10 \%$ de saturação por $\mathrm{Na}$ no complexo de troca, inibiu a absorção de $\mathrm{K}$ e reduziu o crescimento das plântulas de arroz, assim como diminuiu as relações $\mathrm{K} / \mathrm{Na}, \mathrm{Ca} / \mathrm{Na}$ e $\mathrm{Mg} / \mathrm{Na}$ no tecido. A interação entre manejo da adubação $x$ salinidade reduziu o teor de Ca trocável no solo, aumentou o teor de Na na parte aérea e reduziu a relação $\mathrm{Ca} / \mathrm{Na}$ na parte aérea do arroz.
\end{abstract}

Termos de indexação: saturação por sódio, Oryza sativa, potássio, cálcio e magnésio.

\footnotetext{
(1) Trabalho apresentado como parte das exigências da disciplina de Relação Solo-Planta, do Programa de Pós-Graduação em Ciência do Solo da Universidade Federal do Rio Grande do Sul. Recebido para publicação em abril de 2008 e aprovado em janeiro de 2009 .

${ }^{(2)}$ Doutorando, Programa de Pós Graduação em Ciência do Solo da Universidade Federal do Rio Grande do Sul - UFRGS. Av. Bento Golçalves 7712, CEP 91540-000 Porto Alegre (RS). E-mail: felipecamposcarmona@hotmail.com

${ }^{(3)}$ Professor Adjunto, Programa de Pós Graduação em Ciência do Solo, UFRGS. Bolsista CNPq. E-mail: ibanghi@ufrgs.br

(4) Professor Adjunto, Programa de Pós Graduação em Ciência do Solo, UFRGS. Bolsista CNPq. E-mail: egon.meurer@ufrgs.br

(5) Doutorando, Programa de Pós Graduação em Ciência do Solo, UFRGS. E-mail: mjhrs@hotmail.com

${ }^{(6)}$ Estudante de graduação em Agronomia, UFRGS. E-mail: isquierdofraga@yahoo.com.br
} 


\title{
SUMMARY: INITIAL GROWTH OF FLOODED RICE AND CATION ABSORPTION ACCORDING TO POTASSIUM FERTILIZER MANAGEMENT AND SOIL SALINITY
}

\begin{abstract}
The use of water for rice irrigation in Rio Grande do Sul, Brazil, where the water courses are connected with the sea, may cause salt accumulation in the soil at harmful levels for the establishment of rice plants in the following years, especially when high rates of potassium fertilizer are applied in the plant rows. The study was carried out with the purpose of evaluating the effect of potassium chloride management on the establishment and absorption of cations by rice plants (variety IRGA 417) in a soil with different levels of sodium saturation. A Typic Hapludalf was used with sodium saturation of 5,10 and $20 \%$ and three potassium chloride managements: an amount of $120 \mathrm{~kg} \mathrm{ha}^{-1} \mathrm{~K}_{2} \mathrm{O}$ broadcast; $120 \mathrm{~kg} \mathrm{ha}^{-1} \mathrm{~K}_{2} \mathrm{O}$ in the row; $60 \mathrm{~kg} \mathrm{ha}^{-1} \mathrm{~K}_{2} \mathrm{O}$ in the row; and a control without application of salt or fertilizer. The plant stand was unaffected by soil salinity or potassium chloride management. Soil salinity, however, affected plant ontogeny by delaying seedling emergence. Soil salinity above sodium saturation of $10 \%$, inhibited Kabsorption, reduced seedling growth and reduced the ratio of $\mathrm{K} / \mathrm{Na}, \mathrm{Ca} / \mathrm{Na}$ and $\mathrm{Mg} / \mathrm{Na}$ in plant tissues. The interaction of fertilizer management us salinity reduted the exchangeable Ca content in the soil, increased Na shoot content and reduted $\mathrm{Ca} / \mathrm{Na}$ relation in rice shoots.
\end{abstract}

Index terms: sodium saturation, Oryza sativa, potassium, calcium and magnesium.

\section{INTRODUÇÃO}

A produção de arroz no Brasil ocorre, majoritariamente, nas lavouras irrigadas do Rio Grande do Sul (RS), que ocupam cerca de $30 \%$ da área cultivada e contribuem com $53 \%$ da produção nacional desse cereal (CONAB, 2007). Algumas áreas do RS apresentam limitações ao cultivo do arroz irrigado, sendo a salinidade da água de irrigação um problema que afeta frequentemente lavouras das Planícies Costeiras à Laguna dos Patos e da região sul do Rio Grande do Sul. Cerca de 200.000 ha de várzeas utilizadas na atividade orizícola podem ser afetadas por sais na água de irrigação (Machado \& Terres, 1995), sendo o principal o $\mathrm{NaCl}$ (Asch et al., 2000). Os mananciais hídricos que se ligam ao Oceano Atlântico, em especial a Laguna dos Patos, tendem a apresentar aumento dos teores de sais solúveis, comumente em épocas de baixa precipitação pluviométrica (Marcolin et al., 2005). Os períodos críticos da cultura do arroz irrigado ao excesso de sais na água são os estádios de plântula e o reprodutivo. Reduções na emissão de perfilhos e da área foliar fotossinteticamente ativa, assim como o aumento da esterilidade de espiguetas, são alguns dos danos relacionados à salinidade e que reduzem o rendimento do arroz (Ehrler, 1960).

O excesso de sais na água de irrigação pode, além de causar danos à cultura, propiciar acúmulo de $\mathrm{Na}^{+}$ no solo. Dependendo do manejo empregado nessas áreas durante a entressafra, como a implantação de um eficiente sistema de drenagem que permita a extrusão do excesso de $\mathrm{NaCl}$ presente na camada arável ou a aplicação de gesso, que promove a substituição do $\mathrm{Na}^{+}$pelo $\mathrm{Ca}^{2+}$ no complexo sortivo do solo (Santos et al., 2005), o estabelecimento do arroz pode ser prejudicado pela concentração de sais residuais no solo. Assim, em condições salinas, ocorre redução na disponibilidade de água, pelo decréscimo do componente osmótico do potencial hídrico do solo (Tester \& Davenport, 2003). Tal característica é especialmente importante em solos arenosos, que têm baixa capacidade de retenção de água. Essa condição, somada à precipitação pluviométrica do mês de novembro, que é, historicamente, a menor no RS nos 12 meses do ano (IPAGRO, 1989), poderá ter reflexo sobre o desenvolvimento e o crescimento das plantas, uma vez que o efeito salino será agravado. Além disso, a alta concentração de $\mathrm{Na}^{+}$no solo pode prejudicar a

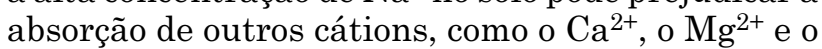
próprio $\mathrm{K}^{+}$, pela competição pelos sítios de absorção nas raízes das plantas de arroz. De acordo com Kawasaki et al. (1983), o prejuízo da salinidade sobre o crescimento das plantas pode ocorrer mais em função da competição pela absorção de nutrientes do que devido à alta pressão osmótica. Além disso, uma alta concentração de $\mathrm{K}^{+}$na linha de semeadura pode implicar menor absorção de $\mathrm{Mg}^{2+}$, por exemplo, já que ocorre efeito antagônico entre ambos (Ding et al., 2006).

A adubação de base com fertilizantes com alto índice salino, como o $\mathrm{KCl}$, realizada na linha de semeadura, pode intensificar o dano prejudicando a germinação e o estabelecimento do arroz em solos afetados por sais. A aplicação desse adubo a lanço pode ser uma alternativa para mitigar os danos que a adubação na linha de semeadura pode causar pelo contato direto 
com as sementes. Além disso, a adubação a lanço feita previamente ao plantio permite melhor aproveitamento da mão-de-obra ao longo do tempo e favorece a semeadura na época recomendada (Carmona et al., 2005), porque o tempo disponível para a semeadura da maioria dos cultivares de arroz, utilizados no RS, é de aproximadamente um mês. Para variedades de ciclo precoce, a semeadura se dá entre 10 de outubro e 10 de novembro (Mariot et al., 2005), período que, devido à ocorrência das chuvas de primavera, proporciona, em média, apenas sete dias úteis de trabalho mecanizado (Stulp et al., 1997). Em propriedades de grande porte, ou naquelas onde a disponibilidade de equipamentos é restrita, a adubação a lanço antes da semeadura pode significar o plantio na época correta, uma vez que plantadoras utilizadas apenas na semeadura têm seu rendimento de trabalho aumentado, em comparação à prática de semeadura e adubação simultânea. Esta prática, porém, aumenta o custo da lavoura, devido ao maior número de operações.

Atualmente, a recomendação de adubação potássica para alta produtividade pode chegar a $110 \mathrm{~kg} \mathrm{ha}^{-1} \mathrm{de}$ $\mathrm{K}_{2} \mathrm{O}$, dependendo da CTC do solo e do incremento de rendimento almejado (SOSBAI, 2007). Conforme a percentagem de saturação por Na no complexo de troca (PST), o efeito prejudicial sobre as plantas de doses nesses patamares pode ser agravado. Este trabalho teve como objetivo avaliar o efeito salino do manejo da adubação potássica sobre o estabelecimento inicial e a absorção de cátions pelo arroz irrigado em solo com diferentes níveis de saturação por Na.

\section{MATERIAL E MÉTODOS}

O trabalho foi realizado na Faculdade de Agronomia da Universidade Federal do Rio Grande do Sul (UFRGS), em Porto Alegre, RS, em área do Departamento de Plantas de Lavoura. O experimento foi implantado em campo, tendo como unidades experimentais bandejas plásticas, com dimensões de 50 × $30 \times 12 \mathrm{~cm}$, preenchidas com a camada arável de um Planossolo Háplico coletado no município de Viamão, na Planície Costeira Interna à Laguna dos Patos. A área de várzea vinha sendo utilizada há mais de cinco anos com pecuária extensiva, não tendo histórico recente de irrigação, adubação e calagem. $\mathrm{Na}$ camada de $0-20 \mathrm{~cm}$, o solo apresentou valores médios de $130 \mathrm{~g} \mathrm{~kg}^{-1}$ de argila; $16 \mathrm{~g} \mathrm{dm}^{-3}$ de matéria orgânica; $\mathrm{pH}$ em água $=4,8 ; \mathrm{Al}$ trocável = $2,5 \mathrm{cmol}_{\mathrm{c}} \mathrm{dm}^{-3} ;$ Ca trocável $=0,30 \mathrm{cmol}_{\mathrm{c}} \mathrm{dm}^{-3} ; \mathrm{Mg}$ trocável $=0,30 \mathrm{cmol}_{\mathrm{c}} \mathrm{dm}^{-3} ; \mathrm{K}$ disponível (Mehlich-1) $=23 \mathrm{mg} \mathrm{dm}^{-3}$; P disponível (Mehlich-1) $=2,7 \mathrm{mg} \mathrm{dm}^{-3}$, $\mathrm{Na}$ disponível (Mehlich-1) $=18 \mathrm{mg} \mathrm{dm}^{-3} ; \mathrm{Al}+\mathrm{H}=$ $9,7 \mathrm{cmol}_{\mathrm{c}} \mathrm{dm}^{-3} ; \mathrm{CTC} \mathrm{pH} \mathrm{7,0}=10,4 \mathrm{cmol}_{\mathrm{c}} \mathrm{dm}^{-3}$ e PST $=0,7 \%$ (Tedesco et al., 1995).

As unidades experimentais foram enterradas no solo após serem feitos, de maneira equidistante, 100 orifícios com diâmetro de $3 \mathrm{~mm}$ no fundo das bandejas, para permitir o fluxo descendente da água, a lixiviação de sais e o fluxo ascendente da água, devido à evapotranspiração. As bandejas, preenchidas com $12 \mathrm{dm}^{3}$ de solo previamente seco e peneirado, foram enterradas até a superfície, com as covas escavadas de acordo com seu formato e dimensões. No leito das covas, foi colocada uma camada de cerca de $3 \mathrm{~cm}$ do mesmo solo para facilitar a acomodação das bandejas e propiciar maior contato possível, através dos orifícios entre o solo da bandeja e o da cova.

Os tratamentos foram constituídos de três níveis de salinidade e de três modos de aplicação de adubo potássico $(\mathrm{KCl})$, com três repetições. Os níveis de salinidade foram obtidos pela adição de $\mathrm{NaCl}$ ao solo para atingir as saturações de $\mathrm{Na}$ na troca de 5,10 e 20 \% da CTC pH 7,0, pela equação:

\section{PST desejada $=\left(\mathrm{Na}^{+} / \mathrm{CTC} \mathrm{pH} 7,0\right) \times 100$}

O manejo da adubação potássica foi realizado da seguinte forma: aplicação do equivalente a $120 \mathrm{~kg} \mathrm{ha}^{-1}$ de $\mathrm{K}_{2} \mathrm{O}$ a lanço; a $120 \mathrm{~kg} \mathrm{ha}^{-1}$ de $\mathrm{K}_{2} \mathrm{O}$ em linha a $60 \mathrm{~kg} \mathrm{ha}^{-1}$ de $\mathrm{K}_{2} \mathrm{O}$ em linha, além da testemunha (fatorial $(3 \times 3)+1)$, gerando 30 de unidades experimentais que foram dispostas totalmente ao acaso na área experimental.

A adubação de fósforo seguiu as recomendações para obtenção de alta produtividade de arroz irrigado (SOSBAI, 2007), sendo aplicado o equivalente a $60 \mathrm{~kg} \mathrm{ha}^{-1}$ de $\mathrm{P}_{2} \mathrm{O}_{5}$, na forma de superfosfato triplo (SFT) granulado, na linha de semeadura. Previamente à semeadura, foram adicionados, em cada bandeja, 2,3 L de água, o equivalente a uma precipitação pluviométrica de $15 \mathrm{~mm}$, para facilitar a abertura dos sulcos de semeadura e a emergência das plântulas. O cultivar utilizado foi o IRGA 417 e a semeadura realizada no dia 5 de novembro de 2007. A densidade foi de $120 \mathrm{~kg} \mathrm{ha}^{-1}$ de sementes, com o espaçamento de $12 \mathrm{~cm}$ entre as linhas, perfazendo um total de cinco linhas por bandeja, na profundidade de semeadura de $3 \mathrm{~cm}$.

O experimento foi conduzido por 23 dias, quando mais de 50 \% das plântulas se encontravam no estádio de desenvolvimento V4 (Counce et al., 2000). Nas adjacências da área experimental, foi instalado um pluviômetro para quantificação da precipitação ocorrida durante a realização do experimento.

Para a análise dos atributos químicos do solo, foram retiradas, no final do período experimental, três subamostras de solo nas entrelinhas de cada bandeja, com trado calador. Foram analisados os teores de $\mathrm{K}^{+}$, $\mathrm{Na}^{+}, \mathrm{Ca}^{2+}, \mathrm{Mg}^{2+}$ e $\mathrm{Al}+\mathrm{H}$ no solo (Tedesco et al., 1995). A contagem de plântulas emergidas para a determinação do estande foi feita nas três linhas centrais de cada bandeja. Foi realizada a coleta da parte aérea de 50 plântulas por bandeja, para a avaliação da biomassa e dos teores de $\mathrm{K}$, Ca e Mg (Tedesco et al., 1995). O material coletado foi seco em estufa a $60^{\circ} \mathrm{C}$ de temperatura, até atingir peso constante. 
Para a determinação da massa das raízes secas, foram selecionadas plântulas representativas de cada tratamento, sendo adotado o método do monólito (Bohm, 1979), retirando-se uma porção de solo, previamente umedecida, com $12 \mathrm{~cm}$ de largura (centralizada na linha de semeadura), $5 \mathrm{~cm}$ de espessura e $8 \mathrm{~cm}$ de profundidade. Esse bloco de terra foi imediatamente colocado em um recipiente com água para a limpeza inicial das raízes. Após a separação, as raízes foram secas em estufa a $60^{\circ} \mathrm{C}$, até atingirem peso constante.

A análise de variância dos dados foi desdobrada em testes no fatorial completo (níveis de salinidade $x$ manejo da adubação potássica) e testes do tratamento testemunha vs média dos demais tratamentos, sendo esta comparação feita pelo uso de uma única prova de contraste. No teste do fatorial completo, avaliaramse os efeitos dos três níveis de PST, dos três modos de adubação potássica e da interação entre ambos. A importância relativa das características, tanto de solo, quanto de planta, foi analisada por meio de comparações múltiplas de médias. Os tratamentos foram agrupados e comparados pelo teste DMS a $5 \%$.

\section{RESULTADOS E DISCUSSÃO}

\section{Salinidade do solo e cátions trocáveis}

Baseado na análise de variância dos atributos de solo avaliados (Quadro 1), observa-se que houve efeito do manejo da adubação (MA) potássica sobre os teores de $\mathrm{K}^{+}(\mathrm{p}<0,001)$ e $\mathrm{Mg}^{2+}$ no solo $(\mathrm{p}<0,05)$. Já a salinidade (S) influenciou os teores de $\mathrm{Na}^{+}(\mathrm{p}<0,001)$, $\mathrm{Ca}^{2+}(\mathrm{p}<0,001), \mathrm{Mg}^{2+}(\mathrm{p}<0,01)$ e a percentagem de saturação por $\mathrm{Na}$ na troca ao final do experimento (PSTf) $(\mathrm{p}<0,001)$. Houve efeito interativo (MA $x \mathrm{~S})$ sobre os teores de $\mathrm{Ca}^{2+}(\mathrm{p}<0,05)$. Na comparação entre a testemunha e os demais tratamentos, houve diferença entre os teores de $\mathrm{Na}^{+}(\mathrm{p}<0,001), \mathrm{K}^{+}$ $(p<0,001), \operatorname{Mg}^{2+}(p<0,01)$ e PSTf $(p<0,001)$.
A interação MA $\times$ S ( $p<0,05)$, para os teores de $\mathrm{Ca}^{2+}$ trocável do solo (Figura 1), evidenciou que, no nível de $10 \%$ de PST, a adubação com $120 \mathrm{~kg} \mathrm{ha}^{-1}$ $\mathrm{K}_{2} \mathrm{O}$, tanto a lanço quanto em linha, resultou em menores teores de $\mathrm{Ca}^{2+}$ trocável em relação ao tratamento com metade da dose de adubo, aplicado em linha. Nesse caso, as maiores doses de K parecem ter contribuído, assim como o nível de $\mathrm{Na}^{+}$, para maior saída de $\mathrm{Ca}^{2+}$ do solo das bandejas, pela competição pelos sítios de troca no solo. Já na PST de $20 \%$, esse efeito foi menos evidente e ocorreu somente no tratamento com a adição do equivalente a $120 \mathrm{~kg} \mathrm{ha}^{-1}$ $\mathrm{K}_{2} \mathrm{O}$ a lanço.

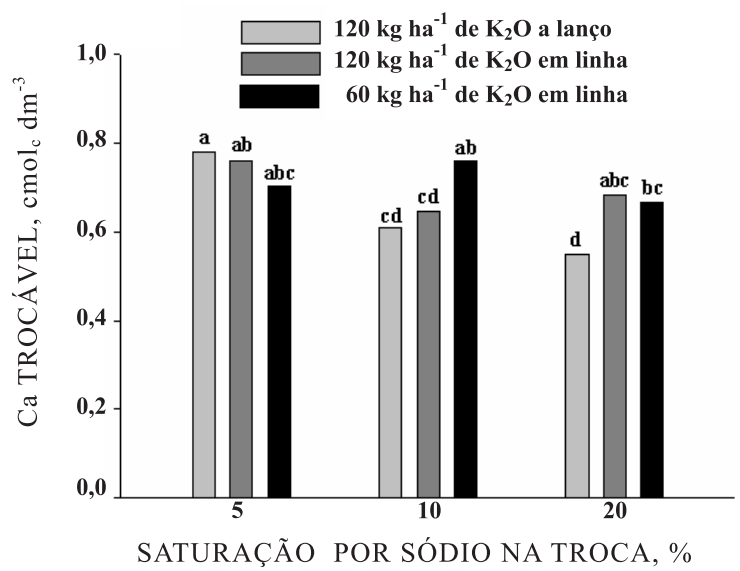

Figura 1. Teor de cálcio trocável no solo em função do manejo da adubação potássica e de níveis de salinidade no solo. Médias seguidas pela mesma letra não diferem entre si pelo teste DMS, a $5 \%$.

Na comparação entre as médias dos atributos químicos do solo, sob diferentes níveis de salinidade (Quadro 2), o incremento da salinidade provocou aumento nos teores de $\mathrm{Na}$ trocável $(\mathrm{p}<0,05)$ e respectiva saturação (PST) no complexo de troca $(\mathrm{p}<0,05)$, como era esperado. Embora os teores e a saturação por $\mathrm{Na}$ tenham aumentado com os níveis

Quadro 1. Análise de variância referente aos teores de cátions, à acidez total, à capacidade de troca de cátions (CTC) e à percentagem de saturação por sódio na troca no final do experimento (PSTf), em função do manejo da adubação potássica e dos níveis de salinidade no solo

\begin{tabular}{|c|c|c|c|c|c|c|c|c|}
\hline \multirow{2}{*}{ Fonte de variação } & \multirow{2}{*}{ GL } & \multicolumn{7}{|c|}{ Quadrado médio } \\
\hline & & Na troc. & K troc. & $\begin{array}{c}\text { Ca troc. } \\
\times 10^{3}\end{array}$ & $\begin{array}{c}\text { Mg troc. } \\
\quad \times 10^{3}\end{array}$ & $\begin{array}{c}\mathrm{Al}+\mathrm{H} \\
\times 10^{2}\end{array}$ & $\begin{array}{l}\text { CTC } \\
\times 10^{2}\end{array}$ & $\begin{array}{r}\text { PSTf } \\
\times 10\end{array}$ \\
\hline Manejo da adubação (MA) & 2 & 337 & $15.348^{* * *}$ & 10,1 & $19,0^{*}$ & 34,6 & 54,1 & 2,93 \\
\hline Salinidade (S) & 2 & $14.654^{* * *}$ & 515 & $30,3^{* *}$ & $23,2^{* *}$ & 1,22 & 8,2 & $294 * * *$ \\
\hline MA x S & 4 & 183 & 716 & $14,4^{*}$ & 6,12 & 206 & 191 & 2,1 \\
\hline Testemunha us fatorial & 1 & $17.537^{* * *}$ & $10.855^{* * *}$ & 4,71 & $29,1^{* *}$ & 208 & 105 & $290 * * *$ \\
\hline Erro & 18 & 249 & 369 & 3,22 & 3,19 & 90,3 & 97,1 & 4,61 \\
\hline
\end{tabular}


Quadro 2. Efeito de níveis de salinidade do solo sobre os teores de cátions, a acidez total, a capacidade de troca de cátions (CTC) e a percentagem de saturação por sódio na troca no final do experimento (PSTf). Valores médios calculados entre os diferentes manejos da adubação potássica

\begin{tabular}{|c|c|c|c|c|c|}
\hline \multirow{2}{*}{ Característica do solo } & \multicolumn{3}{|c|}{$\begin{array}{l}\text { Fatorial completo } \\
\text { Nível de salinidade }\end{array}$} & \multicolumn{2}{|c|}{ Fatorial $v$ s testemunha } \\
\hline & 5 & 10 & 20 & Média & Test. \\
\hline & \multicolumn{3}{|c|}{$\overline{-} \%$} & & \\
\hline $\mathrm{Na}$ trocável $^{(1)}\left(\mathrm{mg} \mathrm{dm}^{-3}\right)$ & $53 \mathrm{c}$ & $94 \mathrm{~b}$ & $134 \mathrm{a}$ & $94 \mathrm{~A}$ & $13 \mathrm{~B}$ \\
\hline K trocável ${ }^{(1)}\left(\mathrm{mg} \mathrm{dm}^{-3}\right)$ & $88 \mathrm{a}$ & $74 \mathrm{a}$ & $85 \mathrm{a}$ & $82 \mathrm{~A}$ & $19 \mathrm{~B}$ \\
\hline Ca trocável ${ }^{(2)}\left(\mathrm{cmol}_{\mathrm{c}} \mathrm{dm}^{-3}\right)$ & $0,75 \mathrm{a}$ & $0,67 \mathrm{ab}$ & $0,63 \mathrm{~b}$ & $0,68 \mathrm{~A}$ & $0,70 \mathrm{~A}$ \\
\hline Mg trocável ${ }^{(2)}\left(\mathrm{cmol}_{\mathrm{c}} \mathrm{dm}^{-3}\right)$ & $0,40 \mathrm{a}$ & $0,40 \mathrm{a}$ & $0,31 \mathrm{a}$ & $0,37 \mathrm{~B}$ & $0,47 \mathrm{~A}$ \\
\hline $\mathrm{Al}+\mathrm{H}^{(3)}\left(\mathrm{cmol}_{\mathrm{c}} \mathrm{dm}^{-3}\right)$ & $8,2 \mathrm{a}$ & $8,1 \mathrm{a}$ & $8,1 \mathrm{a}$ & $8,1 \mathrm{~A}$ & $9,1 \mathrm{~A}$ \\
\hline CTC pH 7,0 $\left(\mathrm{cmol}_{\mathrm{c}} \mathrm{dm}^{-3}\right)$ & $9,6 \mathrm{a}$ & $9,8 \mathrm{a}$ & $9,8 \mathrm{a}$ & $9,7 \mathrm{~A}$ & $10,3 \mathrm{~A}$ \\
\hline PSTf (\%) & $2,4 \mathrm{c}$ & $4,3 \mathrm{~b}$ & $6,0 \mathrm{a}$ & $4,2 \mathrm{~A}$ & $0,5 \mathrm{~B}$ \\
\hline
\end{tabular}

(1) Extrator Mehlich-1. ${ }^{(2)}$ Extrator KCl 1,0 mol L ${ }^{-1} .{ }^{(3)}$ Bissani \& Escosteguy, 1999. Médias seguidas pela mesma letra minúscula, na linha, não diferem entre si na comparação do fatorial completo, pelo teste DMS, a $5 \%$. Médias seguidas pela mesma letra maiúscula, na linha, não diferem entre si na comparação fatorial completo vs testemunha pelo teste DMS, a 5 \%.

de salinidade, os valores de saturação por $\mathrm{Na}$ no final do experimento (PSTf), após 23 dias da aplicação, são bastante inferiores em relação aos iniciais (Quadro 2). A redução dos teores de $\mathrm{Na}^{+}$no solo até determinado ponto era esperada, visto que a camada de solo nas bandejas era de apenas $8 \mathrm{~cm}$, estando, portanto, sujeita à maior ação física das raízes, o que aumenta a permeabilidade e a condutividade hidráulica do solo, facilitando a lixiviação de sais. A alta redução da condição salina deve-se, portanto, principalmente à quantidade total de chuva ocorrida durante a execução do experimento, que foi de $103 \mathrm{~mm}$. Isso, com mais os $15 \mathrm{~mm}$ adicionados na implantação do trabalho, supera amplamente a média histórica do Município de Porto Alegre no mês de novembro, que é de $72 \mathrm{~mm}$ (IPAGRO, 1989). Além disso, a própria absorção de Na pelas plântulas de arroz pode ter contribuído para essa diminuição (McNeal et al., 1977). Pode-se considerar também que a solubilização de carbonatos nativos do solo e a presença de $\mathrm{CO}_{2}$ liberado pela atividade biológica das raízes podem ter deslocado parte do $\mathrm{Na}^{+}$dos sítios de troca, facilitando sua saída do sistema (Chhabra \& Abrol, 1977).

Com relação aos demais cátions, na comparação no fatorial completo, o teor de Ca trocável diminuiu com o aumento da salinidade, o que não ocorreu na comparação fatorial vs testemunha (Quadro 2). Já em relação ao Mg trocável, foi verificado o contrário, com a diminuição da concentração média desse cátion em relação à testemunha $(p<0,05)$. Isso deve ter ocorrido pela adição simultânea de $\mathrm{KCl}$ e de $\mathrm{NaCl}$ ao solo, o que causou o deslocamento de $\mathrm{Ca}^{2+}$ e sobretudo de $\mathrm{Mg}^{2+}$ dos sítios do complexo de troca do solo (Barber, 1995).

O manejo da adubação potássica (Quadro 3) influenciou, como era de se esperar, o teor de $\mathrm{K}^{+}$no solo, e a maior concentração desse íon foi obtida quando da aplicação do fertilizante a lanço $(p<0,05)$. Embora a quantidade aplicada tenha sido a mesma em relação ao tratamento com $120 \mathrm{~kg} \mathrm{ha}^{-1}$ de $\mathrm{K}_{2} \mathrm{O}$ em linha, a amostragem do solo, realizada nas entrelinhas, parece ter influenciado o resultado, porque não se verificou diferença $(p>0,05)$ entre os dois tratamentos em que a aplicação do fertilizante fora realizada em linha. Os teores de $\mathrm{Mg}^{2+}$ no solo não foram influenciados $(p>0,05)$ pelo manejo da adubação no fatorial completo. Entretanto, o tratamento testemunha apresentou maior teor $(\mathrm{p}<0,05)$ desse nutriente em relação à média dos demais tratamentos, assim como verificado pelo efeito da salinidade (Quadro 2), comprovando que esse nutriente é mais facilmente lavável no solo.

Os teores médios de $\mathrm{K}$ e Na trocáveis da parcela testemunha foram menores em relação à média dos demais tratamentos de salinidade (Quadro 2) e de manejo da adubação potássica (Quadro 3), pelo efeito da aplicação de $\mathrm{NaCl}$ (níveis de salinidade) junto com $\mathrm{KCl}$ (manejo da adubação potássica), que não foram aplicados no tratamento testemunha.

\section{Estabelecimento e crescimento das plântulas de arroz}

O estande de plântulas não foi afetado $(p>0,05)$ pelos níveis de salinidade do solo ou pelo modo de aplicação do fertilizante potássico (Quadros 4, 5 e 6). $\mathrm{O}$ efeito nocivo da salinidade sobre esse parâmetro, principalmente quando associado à aplicação localizada de adubos com alto índice salino, como o KCl, observado em genótipos sensíveis por Oster et al. (1984), não se manifestou neste trabalho, mesmo em cultivar (IRGA 417) tido como sensível ao efeito da salinidade (Marcolin \& Macedo, 2001). Esses autores, entretanto, constataram efeito deletério sobre a esterilidade de espiguetas, parâmetro não avaliado neste estudo. 
O desenvolvimento das plântulas (Quadro 4), avaliado pela biomassa da parte aérea (BPA) e pela biomassa de raízes (BR), foi afetado tanto pelo manejo da adubação $(p<0,05)$ quanto pela salinidade do solo ( $p<0,001)$, não havendo, porém, efeito de interação entre esses dois fatores. Na comparação testemunha vs fatorial, com exceção do estande de plântulas, que foi similar, as demais características analisadas foram maiores na testemunha $(p<0,05)$, quer em relação à salinidade (Quadro 5), quer em relação ao manejo da adubação potássica (Quadro 6).

Na comparação entre os níveis de salinidade no fatorial completo, nota-se que, embora não tenha havido efeito sobre a emergência das plântulas, houve efeito sobre seu desenvolvimento (ontogenia), com reflexos negativos $(p<0,05)$ no acúmulo de BPA e na BR (Quadro 5), em razão do atraso na emergência das plântulas com o grau de salinidade do solo em relação à testemunha: dois dias nos tratamentos com PST de $5 \%$ e até sete dias nos tratamentos com PST de 10 e
20 \% de saturação por Na na troca. Embora muitas plantas possuam mecanismo de ajuste osmótico, que se dá com a compartimentação de íons contidos nos vacúolos das células, e consigam sobreviver, o fato de parte da energia ser utilizada nesse mecanismo pode se refletir negativamente no crescimento e no desenvolvimento das estruturas vegetais (Taiz \& Zeiger, 2002). Esse parece ter sido o caso nos tratamentos com PST de 10 e $20 \%$, mas não no de $5 \%$, que apresentou quantidade de material vegetal semelhante à do tratamento testemunha. Isso pode ter ocorrido pelo fato de, até determinado nível de salinidade, a compartimentalização do Na nos vacúolos poder evitar os efeitos deletérios desse elemento no citosol, mantendo o potencial osmótico da célula e minimizando o déficit hídrico em um ambiente salino (Castillo et al., 2007).

Como houve retardamento na emergência, a maioria das plântulas cultivadas nos solos com PST de 10 e $20 \%$ não chegou a atingir o perfilhamento por

Quadro 3. Efeito do manejo da adubação potássica sobre os teores de cátions, a acidez total, a capacidade de troca de cátions (CTC) e a percentagem de saturação por sódio na troca no final do experimento (PSTf). Valores médios calculados entre os níveis de salinidade do solo

\begin{tabular}{|c|c|c|c|c|c|}
\hline \multirow{2}{*}{ Característica do solo } & \multicolumn{2}{|c|}{$\begin{array}{c}\text { Fatorial completo } \\
\text { Manejo da adubação potássica }\end{array}$} & & \multicolumn{2}{|c|}{ Fatorial $v$ s testemunha } \\
\hline & $\begin{array}{c}120 \mathrm{~kg} \mathrm{ha}^{-1} \\
\text { de } \mathrm{K}_{2} \mathrm{O} \text { a lanço }\end{array}$ & $\begin{array}{c}120 \mathrm{~kg} \mathrm{ha}^{-1} \\
\text { de } \mathrm{K}_{2} \mathrm{O} \text { em linha }\end{array}$ & $\begin{array}{c}60 \mathrm{~kg} \mathrm{ha}^{-1} \\
\text { de } \mathrm{K}_{2} \mathrm{O} \text { em linha }\end{array}$ & Média & Test. \\
\hline $\mathrm{Na}_{\text {trocável }}{ }^{(1)}\left(\mathrm{mg} \mathrm{dm}^{-3}\right)$ & $94 \mathrm{a}$ & $88 \mathrm{a}$ & $100 \mathrm{a}$ & $94 \mathrm{~A}$ & $13 \mathrm{~B}$ \\
\hline $\mathrm{K}_{\text {trocável }}{ }^{(1)}\left(\mathrm{mg} \mathrm{dm}^{-3}\right)$ & $128 \mathrm{a}$ & $70 \mathrm{~b}$ & $48 \mathrm{~b}$ & $82 \mathrm{~A}$ & $19 \mathrm{~B}$ \\
\hline Ca trocável ${ }^{(2)}\left(\mathrm{cmol}_{\mathrm{c}} \mathrm{dm}^{-3}\right)$ & $0,65 \mathrm{a}$ & $0,7 \mathrm{a}$ & $0,71 \mathrm{a}$ & $0,69 \mathrm{~A}$ & $0,70 \mathrm{~A}$ \\
\hline $\mathrm{Mg}$ trocável $^{(2)}\left(\mathrm{cmol}_{\mathrm{c}} \mathrm{dm}^{-3}\right)$ & $0,33 \mathrm{a}$ & $0,36 \mathrm{a}$ & $0,42 \mathrm{a}$ & $0,37 \mathrm{~B}$ & $0,47 \mathrm{~A}$ \\
\hline $\mathrm{Al}+\mathrm{H}^{(3)}\left(\mathrm{cmol}_{\mathrm{c}} \mathrm{dm}^{-3}\right)$ & $8,2 \mathrm{a}$ & $7,9 \mathrm{a}$ & $8,3 \mathrm{a}$ & $8,1 \mathrm{~A}$ & $9,1 \mathrm{~A}$ \\
\hline CTC pH 7,0 $\left(\mathrm{cmol}_{\mathrm{c}} \mathrm{dm}^{-3}\right)$ & $9,8 \mathrm{a}$ & $9,5 \mathrm{a}$ & $9,9 \mathrm{a}$ & $9,7 \mathrm{~A}$ & $10,3 \mathrm{~A}$ \\
\hline PSTf $(\%)$ & $4,2 \mathrm{a}$ & $4,1 \mathrm{a}$ & $4,4 \mathrm{a}$ & $4,2 \mathrm{~A}$ & $0,5 \mathrm{~B}$ \\
\hline
\end{tabular}

(1) Extrator Mehlich-1. ${ }^{(2)}$ Extrator $\mathrm{KCl} \mathrm{1,0} \mathrm{mol} \mathrm{L}^{-1} .{ }^{(3)}$ Bissani \& Escosteguy (1999). Médias seguidas pela mesma letra minúscula, na linha, não diferem entre si na comparação do fatorial completo, pelo teste DMS, a $5 \%$. Médias seguidas pela mesma letra maiúscula, na linha, não diferem entre si na comparação fatorial completo vs testemunha pelo teste DMS, a $5 \%$.

Quadro 4. Análise de variância referente ao estande, à biomassa da parte aérea (BPA), à biomassa de raízes (BR) e à relação raiz/parte aérea (R/PA) de plântulas de arroz, em função do manejo da adubação potássica e níveis de salinidade no solo

\begin{tabular}{|c|c|c|c|c|c|}
\hline \multirow{2}{*}{ Fonte de variação } & \multirow{2}{*}{ GL } & \multicolumn{4}{|c|}{ Quadrado médio } \\
\hline & & Estande & BPA & BR & R/PA \\
\hline Manejo da adubação (MA) & 2 & 939 & $1.670^{*}$ & $1.502^{*}$ & 911 \\
\hline Salinidade (S) & 2 & 1.096 & $15.172^{* * *}$ & $9.542^{* * *}$ & 46 \\
\hline $\mathrm{MA} \times \mathrm{S}$ & 4 & 196 & 380 & 545 & 389 \\
\hline Testemunha vs fatorial & 1 & 548 & $2.283^{*}$ & $33.249^{* * *}$ & $14.890^{* * *}$ \\
\hline Erro & 18 & 392 & 383 & 396 & 451 \\
\hline
\end{tabular}

***, **, *: significativo a $0,1,1$ e $5 \%$, pelo teste "F", respectivamente. 
Quadro 5. Efeito de níveis de salinidade do solo sobre o estande, a biomassa da parte aérea (BPA), a biomassa de raízes (BR), e a relação raiz/parte aérea (R/PA) de plântulas de arroz. Valores médios calculados entre os diferentes manejos da adubação potássica

\begin{tabular}{|c|c|c|c|c|c|}
\hline \multirow[t]{2}{*}{ Característica da planta } & \multicolumn{3}{|c|}{$\begin{array}{l}\text { Fatorial completo } \\
\text { Nível de salinidade }\end{array}$} & \multicolumn{2}{|c|}{ Fatorial $v s$ testemunha } \\
\hline & 5 & 10 & 20 & Média & Test. \\
\hline \multicolumn{6}{|c|}{$\%$} \\
\hline Estande (plantas $\mathrm{m}^{-2}$ ) & $322 \mathrm{a}$ & $307 \mathrm{a}$ & $324 \mathrm{a}$ & $317 \mathrm{~A}$ & $302 \mathrm{~A}$ \\
\hline $\mathrm{BPA}\left(\mathrm{kg} \mathrm{ha}^{-1}\right)$ & $140 \mathrm{a}$ & $88 \mathrm{~b}$ & $59 \mathrm{~b}$ & $96 \mathrm{~B}$ & $124 \mathrm{~A}$ \\
\hline $\mathrm{BR}\left(\mathrm{kg} \mathrm{ha}^{-1}\right)$ & $112 \mathrm{a}$ & $73 \mathrm{~b}$ & $48 \mathrm{~b}$ & $78 \mathrm{~B}$ & $189 \mathrm{~A}$ \\
\hline $\mathrm{R} / \mathrm{PA}$ & $0,82 \mathrm{a}$ & $0,77 \mathrm{a}$ & $0,79 \mathrm{a}$ & $0,79 \mathrm{~B}$ & $1,54 \mathrm{~A}$ \\
\hline
\end{tabular}

Médias seguidas pela mesma letra minúscula, na linha, não diferem entre si na comparação do fatorial completo, pelo teste DMS, a $5 \%$. Médias seguidas pela mesma letra maiúscula, na linha, não diferem entre si na comparação fatorial completo $v s$ testemunha pelo teste DMS, a $5 \%$.

Quadro 6. Efeito do manejo da adubação potássica sobre o estande, a biomassa da parte aérea (BPA), a biomassa de raízes (BR), e a relação raiz/parte aérea (R/PA) de plântulas de arroz. Valores médios calculados entre níveis de salinidade do solo

\begin{tabular}{|c|c|c|c|c|c|}
\hline \multirow{3}{*}{ Característica da planta } & \multicolumn{3}{|c|}{ Fatorial completo } & \multirow{2}{*}{\multicolumn{2}{|c|}{ Fatorial vs testemunha }} \\
\hline & \multicolumn{3}{|c|}{ Manejo da adubação potássica } & & \\
\hline & $\begin{array}{c}120 \mathrm{~kg} \mathrm{ha}^{-1} \\
\text { de } \mathrm{K}_{2} \mathrm{O} \text { a lanço }\end{array}$ & $\begin{array}{c}120 \mathrm{~kg} \mathrm{ha}^{-1} \\
\text { de } \mathrm{K}_{2} \mathrm{O} \text { em linha }\end{array}$ & $\begin{array}{c}60 \mathrm{~kg} \mathrm{ha}^{-1} \\
\text { de } \mathrm{K}_{2} \mathrm{O} \text { em linha }\end{array}$ & Média & Test. \\
\hline Estande (plantas $\mathrm{m}^{-2}$ ) & $319 \mathrm{a}$ & $306 \mathrm{a}$ & $326 \mathrm{a}$ & $317 \mathrm{~A}$ & $302 \mathrm{~A}$ \\
\hline BPA (kg ha $\left.{ }^{-1}\right)$ & $94 \mathrm{a}$ & $82 \mathrm{a}$ & $110 \mathrm{a}$ & $95 \mathrm{~B}$ & $124 \mathrm{~A}$ \\
\hline $\mathrm{BR}\left(\mathrm{kg} \mathrm{ha} \mathrm{a}^{-1}\right)$ & $81 \mathrm{a}$ & $64 \mathrm{a}$ & $89 \mathrm{a}$ & $78 \mathrm{~B}$ & $189 \mathrm{~A}$ \\
\hline $\mathrm{R} / \mathrm{PA}$ & $0,91 \mathrm{a}$ & $0,77 \mathrm{a}$ & $0,71 \mathrm{a}$ & $0,79 \mathrm{~B}$ & $1,54 \mathrm{~A}$ \\
\hline
\end{tabular}

Médias seguidas pela mesma letra minúscula, na linha, não diferem entre si na comparação do fatorial completo, pelo teste DMS, a $5 \%$. Médias seguidas pela mesma letra maiúscula, na linha, não diferem entre si na comparação fatorial completo vs testemunha pelo teste DMS, a $5 \%$.

ocasião do encerramento do trabalho, pois ainda se encontravam com apenas três folhas. Melo et al. (2006) também observaram efeito negativo da salinidade sobre o perfilhamento das plantas, sendo que o alto perfilhamento do arroz irrigado é uma das características associadas ao alto rendimento de grãos (Counce et al., 1989). Nesse sentido, a salinidade do solo contribui para a redução da fotossíntese, devido à diminuição da disponibilidade de $\mathrm{CO}_{2}$ no interior das folhas, pelo fechamento dos estômatos, o que acarreta uma série de efeitos acumulativos, que geram menor produção de foto-assimilados nas folhas, afetando a produção de biomassa aérea (Sultana et al., 1999).

Os efeitos da salinidade sobre o crescimento radicular foram mais pronunciados (Quadro 5), com maior evidência na comparação entre a média dos tratamentos no fatorial com a testemunha. Isto porque o estresse por salinidade prejudica a absorção de nutrientes, em face da forte competição química do $\mathrm{Na}$. A alta exigência, em termos de capacidade de transporte e seletividade, requer, em muitos casos, energia metabólica produzida a partir de carboidratos das raízes, o que afeta o seu desenvolvimento (Welfare et al., 1996). Aparentemente, a baixa fertilidade natural do solo e a ausência de adubação levaram as plântulas do tratamento testemunha a explorar maior área de solo para terem supridas suas demandas nutricionais (Barber, 1995). Isso fica mais evidente na relação raiz/parte aérea (Quadro 5). Ela foi maior nesse tratamento (testemunha) em relação aos demais, que não diferiram entre si. Além disso, essa relação superou amplamente o valor da unidade (1), o que é pouco comum, uma vez que a biomassa da parte aérea das plantas cultivadas tende a ser maior do que a das raízes, mesmo em plantas jovens. Segundo Lopes et al. (1994), o maior crescimento das raízes nas fases iniciais de desenvolvimento do arroz irrigado ocorre inicialmente para garantir a ancoragem da planta e o suprimento de água e nutrientes para, então, intensificar o crescimento da parte aérea. Turner \& McCauley (1983) já tinham reportado que a taxa de 
crescimento radicular é maior do que a da parte aérea nesta fase da cultura.

O desenvolvimento das plântulas no tratamento testemunha em relação aos diferentes manejos da adubação potássica (Quadro 6) foi semelhante ao verificado em relação aos níveis de salinidade (Quadro 5). Assim, de maneira geral, as plântulas se desenvolveram melhor na ausência da adubação potássica, havendo, ainda, uma tendência de menor crescimento na maior dose (equivalente a $120 \mathrm{~kg} \mathrm{ha}^{-1}$ de $\mathrm{K}_{2} \mathrm{O}$ ), aplicada na linha de semeadura, o que demonstra que o posicionamento, junto às sementes, de altas doses de adubo com elevado índice salino, em solos afetados por sais, pode prejudicar o crescimento inicial das plântulas. Esse efeito foi mais evidente para a biomassa de raízes e relação raiz/parte aérea. Deve-se ressaltar que o desenvolvimento do arroz ocorreu em solo seco, tal como ocorre em cerca de $90 \%$ da área plantada no Estado do Rio Grande do Sul (IRGA, 2008), onde a entrada da água de irrigação ocorre entre duas e quatro semanas após a emergência. Na fase inicial, as raízes tendem a se aprofundar, principalmente em busca da água disponível no solo. Lopes et al. (1994) já se referiam à importância do conhecimento das características do desenvolvimento radicular para o estabelecimento de técnicas adequadas de aplicação e localização de adubos e corretivos.

\section{Absorção de cátions pelo arroz}

A análise de variância, em relação à absorção de cátions pelo arroz (Quadro 7), demonstra que houve influência do manejo da adubação $(p<0,01)$, da salinidade do solo $(p<0,001)$ e interação entre ambos $(\mathrm{p}<0,05)$ sobre o teor de $\mathrm{Na}$ na parte aérea. O manejo da adubação e a salinidade afetaram ainda a quantidade de $\mathrm{Na}$ absorvida $(\mathrm{p}<0,001)$. O K na parte aérea foi afetado, também, pela salinidade $(p<0,05)$. Houve, ainda, diferenças na comparação testemunha vs fatorial para os teores de $\mathrm{Na}$ na parte aérea $(p<0,001), \mathrm{Na}$ absorvido $(\mathrm{p}<0,05)$ e K na parte aérea $(\mathrm{p}<0,001)$
Verificou-se efeito interativo (MA $x$ S) sobre a concentração de $\mathrm{Na}$ na parte aérea das plântulas (Figura 2), que foi menor $(\mathrm{p}<0,05)$ na aplicação da dose integral a lanço na menor PST (5\%) e maior $(p<0,05)$ nas demais (PST 10 e $20 \%$ ), em relação a essa aplicação em linha, refletindo maior ou menor absorção desse nutriente, devido, respectivamente, ao menor ou maior crescimento das plântulas de arroz (Quadros 5 e 6) naquela condição (PST de $5 \%$ e adubação a lanço). Por outro lado, na adubação em linha, a maior concentração de $\mathrm{Na}$ nas plântulas com a aplicação da metade da dose $\left(60 \mathrm{~kg} \mathrm{ha}^{-1}\right.$ de $\left.\mathrm{K}_{2} \mathrm{O}\right)$ nas linhas de semeadura se relaciona com maior absorção $(p<0,05)$ desse nutriente (Quadro 9) e crescimento das plântulas, especialmente da parte aérea (Quadro 6). Esse efeito interativo ocorreu também com a relação $\mathrm{Ca} / \mathrm{Na}$ (Figura 3), demonstrando que a presença de $\mathrm{K}$ junto às sementes pode prejudicar a absorção de $\mathrm{Ca}^{2+}$ mais pronunciadamente. Com o

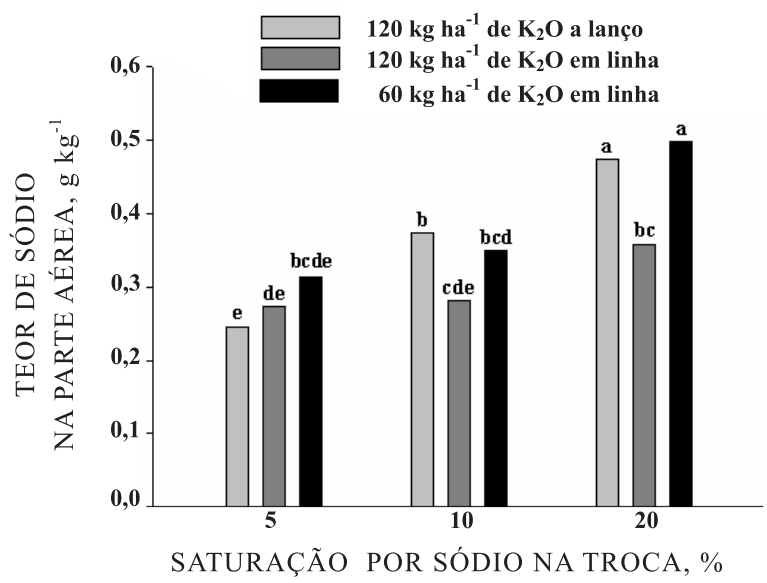

Figura 2. Teor de sódio na parte aérea de plântulas de arroz, em função do manejo da adubação potássica e dos níveis de salinidade no solo. Médias seguidas pela mesma letra não diferem entre si pelo teste DMS, a $5 \%$.

Quadro 7. Resumo da análise de variância referente ao teor de sódio na parte aérea (NaPA), ao sódio absorvido, ao teor de potássio na parte aérea (KPA) e ao potássio absorvido pelas plântulas de arroz, em função do manejo da adubação potássica e de níveis de salinidade no solo

\begin{tabular}{|c|c|c|c|c|c|}
\hline \multirow{2}{*}{ Fonte de variação } & \multirow{2}{*}{ GL } & \multicolumn{4}{|c|}{ Quadrado médio } \\
\hline & & NaPA & $\mathrm{Na}$ absorvido & KPA & K absorvido \\
\hline Manejo da adubação (MA) & 2 & $662^{* *}$ & $2.020 * * *$ & 5,11 & 105,3 \\
\hline Salinidade (S) & 2 & $2.559 * * *$ & $1.710^{* * *}$ & $8,18^{*}$ & 1.240 \\
\hline $\mathrm{MA} \times \mathrm{S}$ & 4 & $216^{*}$ & 130 & 0,98 & 26 \\
\hline Testemunha $v s$ fatorial & 1 & $2.856^{* * *}$ & $680^{*}$ & $177^{* * *}$ & 3,5 \\
\hline Erro & 18 & 72,0 & 130 & 1,69 & 35,2 \\
\hline
\end{tabular}

$* * *, * *, *$ : significativo a $0,1,1$ e $5 \%$, pelo teste "F", respectivamente. 


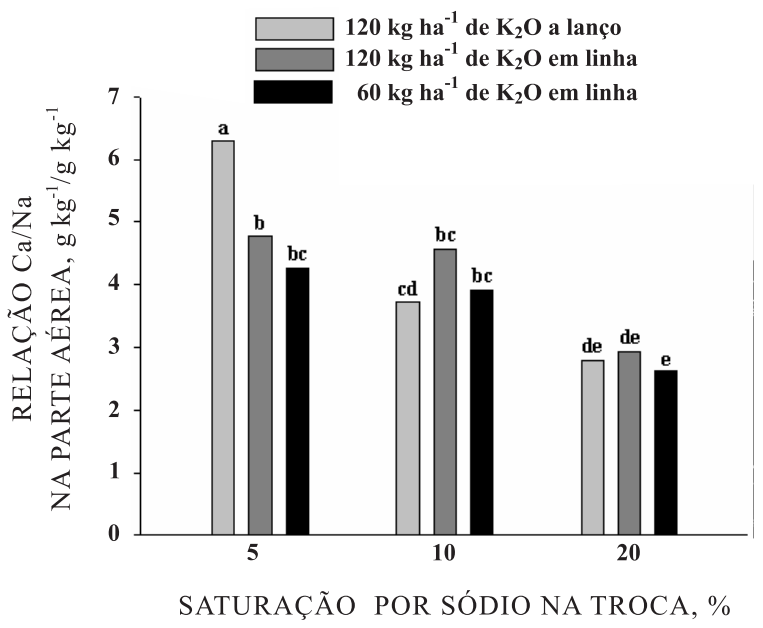

Figura 3. Relação cálcio/sódio na parte aérea de plântulas de arroz, em função do manejo da adubação potássica e dos níveis de salinidade no solo. Médias seguidas pela mesma letra não diferem entre si pelo teste DMS, a $5 \%$.

aumento da salinidade do solo para 10 e $20 \%$, esse efeito foi diminuído, já que a concentração de Na no meio passou a ser mais limitante à absorção de cálcio do que a localização do fertilizante potássico.

Na comparação de médias dessas características, para os diferentes níveis de salinidade (Quadro 8), notase que os teores de $\mathrm{Na}$ no tecido das plântulas aumentaram $(p<0,05)$, como esperado, com os níveis de sua saturação no complexo de troca. A quantidade acumulada na parte aérea, que resulta desse efeito em conjunto com o respectivo efeito no crescimento das plantas (Quadro 5), no entanto, tende a diminuir com a salinidade. A absorção de nutrientes depende da quantidade que chega às raízes, sendo aqueles supridos majoritariamente por fluxo de massa, como os cátions básicos, dependendo do teor na solução do solo e do volume de água transpirada pela cultura (Asch et al., 1997).

Embora o teor de $\mathrm{K}$ nas plântulas não tenha sido afetado, a quantidade total absorvida diminuiu com a salinidade por seu efeito negativo no crescimento delas (Quadro 8), e o inverso ocorreu na comparação dessas com a testemunha. A maior concentração de $\mathrm{Na}$ no tecido, em função do cultivo de arroz em meio salino, impõe um estresse iônico sobre a cultura em adição ao estresse osmótico (Castillo et al., 2007). Neste estudo, esse fato é evidenciado pelos efeitos antagônicos entre os níveis de $\mathrm{Na}^{+}$adicionados ao solo e pela absorção de K pelo arroz (Quadro 8). O excesso de $\mathrm{Na}^{+}$no solo pode causar a perda de íons $\mathrm{K}^{+}$em função da despolarização da membrana e substituição por íons $\mathrm{Na}^{+}$(Cramer et al., 1991). Os dois cátions têm átomos similares e os transportadores de $\mathrm{K}^{+}$são menos específicos em concentrações tóxicas de $\mathrm{Na}^{+}$ (Castillo et al., 2007). A relação entre os íons $\mathrm{K}^{+} \mathrm{e}$ $\mathrm{Na}^{+}$é um indicador de tolerância à salinidade, pois reúne duas características desejáveis: alta absorção de $\mathrm{K}$, necessária para os processos metabólicos e o ajuste osmótico, e a absorção de $\mathrm{Na}$, como um indicador do nível de estresse (Garcia et al., 1997). Corroboram com essa afirmação os resultados deste estudo, uma vez que o cultivar utilizado é sabidamente suscetível à salinidade e apresentou decréscimo na absorção de K (Quadro 8) conforme aumentou a salinidade do solo.

O manejo da adubação potássica pouco influenciou a absorção de $\mathrm{K}$ e $\mathrm{Na}$, pois a única característica afetada foi a quantidade de $\mathrm{Na}$ absorvida, que foi menor na aplicação de $120 \mathrm{~kg} \mathrm{ha}^{-1}$ de $\mathrm{K}_{2} \mathrm{O}$ em linha (Quadro 9), uma vez que o próprio crescimento (Quadro 6) também não fora afetado. Na comparação com a testemunha, os valores dos demais tratamentos são predominantemente menores, pois não receberam aplicação desses elementos.

Quadro 8. Efeito de níveis de salinidade do solo sobre o teor de sódio na parte aérea (NaPA), o sódio absorvido, o teor de potássio na parte aérea (KPA) e o potássio absorvido de plântulas de arroz. Valores médios calculados entre diferentes manejos da adubação potássica

\begin{tabular}{|c|c|c|c|c|c|}
\hline \multirow{3}{*}{ Parâmetro de planta } & \multicolumn{3}{|c|}{ Fatorial completo } & \multicolumn{2}{|c|}{ Fatorial $v$ s testemunha } \\
\hline & \multicolumn{3}{|c|}{ Nível de salinidade } & \multirow[t]{2}{*}{ Média } & \multirow[t]{2}{*}{ Test. } \\
\hline & 5 & 10 & 20 & & \\
\hline & & $\%$ & - & & \\
\hline $\mathrm{NaPA}\left(\mathrm{kg} \mathrm{ha}^{-1}\right)$ & $0,56 \mathrm{~b}$ & $0,67 \mathrm{~b}$ & 0,89 a & $0,70 \mathrm{~A}$ & $0,38 \mathrm{~B}$ \\
\hline $\mathrm{Na}$ absorvido $\left(\mathrm{kg} \mathrm{ha}^{-1}\right)$ & $0,078 \mathrm{a}$ & $0,058 \mathrm{~b}$ & $0,051 \mathrm{~b}$ & $0,063 \mathrm{~A}$ & $0,047 \mathrm{~B}$ \\
\hline $\mathrm{KPA}\left(\mathrm{kg} \mathrm{ha}^{-1}\right)$ & $29,7 \mathrm{a}$ & $30,2 \mathrm{a}$ & $31,5 \mathrm{a}$ & $30,5 \mathrm{~A}$ & $22 \mathrm{~B}$ \\
\hline $\mathrm{K}$ absorvido $\left(\mathrm{kg} \mathrm{ha}^{-1}\right)$ & $4,13 \mathrm{a}$ & $2,66 \mathrm{~b}$ & $1,82 \mathrm{~b}$ & $2,87 \mathrm{~A}$ & $2,80 \mathrm{~A}$ \\
\hline
\end{tabular}

Médias seguidas pela mesma letra minúscula na linha não diferem entre si na comparação do fatorial completo, pelo teste DMS, a $5 \%$. Médias seguidas pela mesma letra maiúscula na linha não diferem entre si na comparação fatorial completo vs testemunha pelo teste DMS, a $5 \%$. 
A análise de variância referente às relações iônicas na parte aérea do arroz (Quadro 10) demonstra que o modo de adubação afeta apenas a relação $\mathrm{K} / \mathrm{Na}$ na parte aérea $(p<0,01)$, enquanto a salinidade influi sobre as relações $\mathrm{K} / \mathrm{Na}(\mathrm{p}<0,01), \mathrm{Ca} / \mathrm{Na}(\mathrm{p}<0,001)$ e $\mathrm{Mg} / \mathrm{Na}(\mathrm{p}<0,001)$. Verifica-se, também, efeito altamente significativo sobre essas três relações, na comparação testemunha vs fatorial. Houve, ainda, interação MA x S $(p<0,05)$ sobre a relação $\mathrm{Ca} / \mathrm{Na}$ no tecido.

Na comparação entre médias nas diferentes PST (Quadro 11), nota-se que as relações avaliadas foram afetadas negativamente em PST do solo a partir de $10 \%$. Da mesma forma, essas relações decresceram com o aumento da salinidade. O desbalanço gerado pelos excessivos teores de $\mathrm{Na}^{+} \mathrm{e}$ Cl- na solução causam decréscimo nos conteúdos de Ke Ca nos tecidos (Ahmad et al., 2007), diminuindo, respectivamente, as relações $\mathrm{K} / \mathrm{Na}$ e $\mathrm{Ca} / \mathrm{Na}$. Isso ocorre porque as células mantêm um balanço entre cátions e ânions. Um aumento no conteúdo de $\mathrm{Cl}$ nas células resultado do alto nível de salinidade aumenta do teor de $\mathrm{Na}$. Como o total de cargas na célula deve ser balanceado, o aumento no teor de $\mathrm{Na}$ resulta em diminuição dos teores de $\mathrm{K} \mathrm{e}$ $\mathrm{Ca}$ (Cramer et al., 1985).
Altos teores de $\mathrm{Na}$, ou baixa relação K/Na no solo, podem deflagrar uma série de processos enzimáticos no citoplasma da planta, permitindo a competição entre o $\mathrm{Na}$ e o K pelos sítios de absorção (Obata et al., 2007), sendo a capacidade da planta em manter alta a relação K/Na no citosol premissa básica para o adequado crescimento em solos salinos (Glenn et al., 1999). As concentrações foliar de íons podem ser usados para distinção entre variedades "Na-inclusoras" e "Na-evitadoras". A alta concentração de $\mathrm{Na}$ nas folhas indica uma "Na-inclusora" e, tendo esta elevada relação $\mathrm{K} / \mathrm{Na}$, tem também a habilidade de absorver $\mathrm{K}$ em detrimento do estresse salino. Por outro lado, "Na-evitadoras" requerem menor quantidade de $\mathrm{K}$ para atingir alta relação $\mathrm{K} / \mathrm{Na}$, e têm, portanto, menor concentração foliar de $\mathrm{Na}$ (Asch et al., 2000). Neste estudo, pode-se considerar, por conseguinte, que a variedade IRGA 417 é uma "Na-inclusora", pois seus teores de $\mathrm{Na}$ no tecido aumentaram com o aumento da salinidade (Quadro 8), porém o cultivar, não teve habilidade para manter a relação K/Na estável no tecido (Quadro 11).

A relação $\mathrm{Ca} / \mathrm{Na}$ chegou, no caso extremo da PST de $20 \%$, a ter um valor cerca de 2,5 vezes inferior ao

Quadro 9. Efeito do manejo da adubação potássica sobre o teor de sódio na parte aérea (NaPA), o sódio absorvido, o teor de potássio na parte aérea (KPA) e o potássio absorvido de plântulas de arroz. Valores médios calculados entre níveis de salinidade do solo

\begin{tabular}{|c|c|c|c|c|c|}
\hline \multirow[t]{2}{*}{ Parâmetro de planta } & \multicolumn{3}{|c|}{$\begin{array}{c}\text { Fatorial completo } \\
\text { Manejo da adubação potássica }\end{array}$} & \multicolumn{2}{|c|}{ Fatorial $v s$ testemunha } \\
\hline & $\begin{array}{c}120 \mathrm{~kg} \mathrm{ha}^{-1} \\
\text { de } \mathrm{K}_{2} \mathrm{O} \text { a lanço }\end{array}$ & $\begin{array}{c}120 \mathrm{~kg} \mathrm{ha}^{-1} \\
\text { de } \mathrm{K}_{2} \mathrm{O} \text { em linha }\end{array}$ & $\begin{array}{c}60 \mathrm{~kg} \mathrm{ha}^{-1} \\
\text { de } \mathrm{K}_{2} \mathrm{O} \mathrm{em} \text { linha }\end{array}$ & Média & Test. \\
\hline $\mathrm{NaPA}\left(\mathrm{g} \mathrm{kg}^{-1}\right)$ & $0,73 \mathrm{a}$ & $0,61 \mathrm{a}$ & $0,77 \mathrm{a}$ & $0,70 \mathrm{~A}$ & $0,38 \mathrm{~B}$ \\
\hline $\mathrm{Na}$ absorvido $\left(\mathrm{kg} \mathrm{ha}^{-1}\right)$ & $0,061 \mathrm{ab}$ & $0,048 \mathrm{~b}$ & $0,078 \mathrm{a}$ & $0,063 \mathrm{~A}$ & $0,047 \mathrm{~B}$ \\
\hline $\mathrm{KPA}\left(\mathrm{g} \mathrm{kg}^{-1}\right)$ & $30,3 \mathrm{a}$ & $31,3 \mathrm{a}$ & $29,8 \mathrm{a}$ & $30,5 \mathrm{~A}$ & $22 \mathrm{~B}$ \\
\hline $\mathrm{K}$ absorvido $\left(\mathrm{kg} \mathrm{ha}^{-1}\right)$ & $2,84 \mathrm{a}$ & $2,54 \mathrm{a}$ & $3,23 \mathrm{a}$ & $2,87 \mathrm{~A}$ & $2,80 \mathrm{~A}$ \\
\hline
\end{tabular}

Médias seguidas pela mesma letra minúscula na linha não diferem entre si na comparação do fatorial completo, pelo teste DMS, a $5 \%$. Médias seguidas pela mesma letra maiúscula na linha não diferem entre si na comparação fatorial completo vs testemunha pelo teste DMS, a $5 \%$.

Quadro 10. Resumo da análise de variância referente às relações potássio/sódio (K/Na), cálcio/sódio (Ca/Na) e magnésio/sódio ( $\mathrm{Mg} / \mathrm{Na}$ ) na parte aérea de plântulas de arroz, em função do manejo da adubação potássica e de níveis de salinidade no solo

\begin{tabular}{|c|c|c|c|c|}
\hline \multirow{2}{*}{ Fonte de variação } & \multirow{2}{*}{ GL } & \multicolumn{3}{|c|}{ Quadrado médio } \\
\hline & & $\mathrm{K} / \mathrm{Na}$ & $\mathrm{Ca} / \mathrm{Na}$ & $\mathrm{Mg} / \mathrm{Na}$ \\
\hline Manejo da adubação (MA) & 2 & $331^{* *}$ & 1,08 & 0,29 \\
\hline Salinidade (S) & 2 & $776^{* *}$ & $12,2^{* * *}$ & $2,1^{* * *}$ \\
\hline $\mathrm{MA} \times \mathrm{S}$ & 4 & 102 & $1,47 *$ & 0,24 \\
\hline Testemunha $v s$ fatorial & 1 & $498^{* *}$ & $24,4^{* * *}$ & $12,67^{* * *}$ \\
\hline Erro & 18 & 45,9 & 0,37 & 0,09 \\
\hline
\end{tabular}

***,**, *: significativo a $0,1,1$ e $5 \%$, pelo teste "F", respectivamente. 
obtido na testemunha (Quadro 11). Esse efeito pode ser também atribuído aos baixos teores de $\mathrm{Ca}^{2+}$ no solo em estudo (Quadros 2 e 3), uma vez que Anil et al. (2005) observaram que a adição de $\mathrm{Ca}^{2+}$ em solução nutritiva salina causou a diminuição da absorção de $\mathrm{Na}$ pelas plantas tanto em variedade tolerante (Pokkali) como em uma suscetível (Jaya) à salinidade. Esses autores afirmam que o aumento da concentração de $\mathrm{Ca}^{2+}$ no meio externo aumenta substancialmente a sobrevivência das plantas em condições de salinidade.

Os efeitos da competição entre cátions no solo frequentemente geram deficiências de $\mathrm{Mg}^{2+}$, especialmente em solos arenosos e em culturas manejadas para alta produtividade. Em solos naturalmente pobres em $\mathrm{Mg}^{2+}$, como o deste estudo, o aumento da salinidade ocasionou a diminuição da relação $\mathrm{Mg} / \mathrm{Na}$ no tecido das plântulas. Segundo Ding et al. (2006), a deficiência de $\mathrm{Mg}$ no tecido do arroz ocasiona redução na biomassa da parte aérea e aumento da biomassa de raízes, incrementando a relação raiz/parte aérea, indicando maior partição de carboidratos dos tecidos para as raízes em baixa disponibilidade de $\mathrm{Mg}^{2+}$. Verificou-se, neste trabalho, que a premissa em relação às raízes é verdadeira apenas no tratamento testemunha (Quadros 5 e 6). Já em relação à BPA (Quadros 5 e 6), seu decréscimo pode estar relacionado não somente ao aumento da salinidade do solo, mas também à diminuição da relação $\mathrm{Mg} / \mathrm{Na}$ no tecido.

O efeito do manejo da adubação potássica sobre as relações nutricionais no tecido do arroz influenciou apenas a relação $\mathrm{K} / \mathrm{Na}$, e a adubação com $120 \mathrm{~kg} \mathrm{ha}^{-1}$ de $\mathrm{K}_{2} \mathrm{O}$ em linha proporcionou maior relação $(\mathrm{p}<0,05)$ entre esses dois íons em comparação com a aplicação com $60 \mathrm{~kg} \mathrm{ha}^{-1}$ de $\mathrm{K}_{2} \mathrm{O}$ em linha (Quadro 12). Isso demonstra que a aplicação de doses de $\mathrm{K}$ para alta produtividade de arroz irrigado, na linha de semeadura, pode mitigar a absorção de $\mathrm{Na}^{+}$pelo arroz na competição pelos sítios de absorção das raízes. Assim como verificado entre os níveis de salinidade (Quadro 11), as relações $\mathrm{K} / \mathrm{Na}, \mathrm{Ca} / \mathrm{Na}$ e $\mathrm{Mg} / \mathrm{Na}$ foram sempre superiores no tratamento testemunha em

Quadro 11. Efeito de níveis de salinidade do solo sobre as relações potássio/sódio (K/Na), cálcio/sódio ( $\mathrm{Ca} / \mathrm{Na}$ ) e magnésio/sódio $(\mathrm{Mg} / \mathrm{Na})$ na parte aérea de plântulas de arroz. Valores médios calculados entre diferentes manejos da adubação potássica

\begin{tabular}{|c|c|c|c|c|c|}
\hline \multirow{3}{*}{ Parâmetro de planta } & \multirow{2}{*}{\multicolumn{3}{|c|}{$\begin{array}{l}\text { Fatorial completo } \\
\text { Nível de salinidade }\end{array}$}} & \multicolumn{2}{|c|}{ Fatorial $v s$ testemunha } \\
\hline & & & & \multirow[t]{2}{*}{ Média } & \multirow[t]{2}{*}{ Test. } \\
\hline & 5 & 10 & 20 & & \\
\hline & - & $\%$ & - & & \\
\hline $\mathrm{K} / \mathrm{Na}$ & $54,5 \mathrm{a}$ & $45,6 \mathrm{ab}$ & $36,0 \mathrm{~b}$ & $45,4 \mathrm{~B}$ & $59,0 \mathrm{~A}$ \\
\hline $\mathrm{Ca} / \mathrm{Na}$ & $5,11 \mathrm{a}$ & $4,07 \mathrm{~b}$ & $2,78 \mathrm{~b}$ & $3,99 \mathrm{~B}$ & $7,00 \mathrm{~A}$ \\
\hline $\mathrm{Mg} / \mathrm{Na}$ & $2,55 \mathrm{a}$ & $2,14 \mathrm{~b}$ & $1,58 \mathrm{c}$ & $2,09 \mathrm{~B}$ & $4,30 \mathrm{~A}$ \\
\hline
\end{tabular}

Médias seguidas pela mesma letra minúscula, na linha, não diferem entre si na comparação do fatorial completo, pelo teste DMS, a $5 \%$. Médias seguidas pela mesma letra maiúscula, na linha, não diferem entre si na comparação fatorial completo vs testemunha pelo teste DMS, a $5 \%$

Quadro 12. Efeito do manejo da adubação potássica sobre as relações potássio/sódio (K/Na), cálcio/sódio $(\mathrm{Ca} / \mathrm{Na})$ e magnésio/sódio $(\mathrm{Mg} / \mathrm{Na})$ na parte aérea de plântulas de arroz. Valores médios calculados entre níveis de salinidade do solo

\begin{tabular}{|c|c|c|c|c|c|}
\hline \multirow{2}{*}{ Parâmetro de planta } & \multicolumn{3}{|c|}{$\begin{array}{c}\text { Fatorial completo } \\
\text { Manejo da adubação potássica }\end{array}$} & \multicolumn{2}{|c|}{ Fatorial vs testemunha } \\
\hline & $\begin{array}{c}120 \mathrm{~kg} \mathrm{ha}^{-1} \\
\text { de } \mathrm{K}_{2} \mathrm{O} \text { a lanço }\end{array}$ & $\begin{array}{c}120 \mathrm{~kg} \mathrm{ha}^{-1} \\
\text { de } \mathrm{K}_{2} \mathrm{O} \mathrm{em} \text { linha }\end{array}$ & $\begin{array}{c}60 \mathrm{~kg} \mathrm{ha}^{-1} \\
\text { de } \mathrm{K}_{2} \mathrm{O} \text { em linha }\end{array}$ & Média & Test. \\
\hline $\mathrm{K} / \mathrm{Na}$ & $45,2 \mathrm{ab}$ & $52,1 \mathrm{a}$ & $40,0 \mathrm{~b}$ & $45,8 \mathrm{~B}$ & $59,0 \mathrm{~A}$ \\
\hline $\mathrm{Ca} / \mathrm{Na}$ & $4,10 \mathrm{a}$ & $3,60 \mathrm{a}$ & $4,27 \mathrm{a}$ & $3,99 \mathrm{~B}$ & $7,00 \mathrm{~A}$ \\
\hline $\mathrm{Mg} / \mathrm{Na}$ & $2,18 \mathrm{a}$ & $1,88 \mathrm{a}$ & $2,20 \mathrm{a}$ & $2,09 \mathrm{~B}$ & $4,3 \mathrm{~A}$ \\
\hline
\end{tabular}

Médias seguidas pela mesma letra minúscula na linha não diferem entre si na comparação do fatorial completo, pelo teste DMS, a $5 \%$. Médias seguidas pela mesma letra maiúscula na linha não diferem entre si na comparação fatorial completo vs testemunha pelo teste DMS, a $5 \%$. 
relação aos demais (Quadro 12), uma vez que nele não foram aplicados sal nem K.

\section{CONCLUSÕES}

1. O estande de plântulas não foi afetado pelos níveis de salinidade do solo e pelo manejo da adubação potássica.

2. A ontogenia da planta foi afetada pela salinidade, com atraso na emergência das plântulas à medida que aquela aumentou.

3. A salinidade do solo, a partir de $10 \%$ de saturação por Na no complexo de troca, resultou em inibição da absorção de K; redução do crescimento das plântulas de arroz, e diminuição das relações dos cátions $\mathrm{K}, \mathrm{Ca} \mathrm{e}$ Mg em relação ao Na no tecido, caracterizando o cultivar de arroz IRGA 417 como uma planta "Na-inclusora".

4. A interação entre o manejo da adubação potássica e a salinidade do solo reduziu o teor de Ca trocável no solo aumentou o teor de Na na parte aérea e reduziu a relação $\mathrm{Ca} / \mathrm{Na}$ na parte aérea do arroz.

\section{LITERATURA CITADA}

AHMAD, M.S.A.; JAVED, F. \& ASHRAF, M. Iso-osmotic effect of $\mathrm{NaCl}$ and $\mathrm{PEG}$ on growth, cations and free proline accumulation in callus tissue of two indica rice (Oryza sativa L.) genotypes. Plant Growth Reg., 53:53-63, 2007.

ANIL, V.S.; KRISHNAMURTHY, P.; KURUVILLA, S.; SUCHARITHA, K.; THOMAS, G. \& MATHEW, M.K. Regulation of the uptake and distribution of $\mathrm{Na}^{+}$in shoots of rice (Oryza sativa) variety Pokkali: Role of $\mathrm{Ca}^{2+}$ in salt tolerance response. Physiol. Plant., 124:451-464, 2005.

ASCH, F.; DINGKUHN, M. \& DÖRFFLING, K. Effects of transpiration on sodium and potassium distribution in salt-stressed irrigated rice. J. Exper. Bot., 48:39, 1997. (Suplemento)

ASCH, F.; DINGKUHN, M.; DÖRFFLING, K. \& MIEZAN, K. Leaf $\mathrm{K} / \mathrm{Na}$ ratio predicts salinity induced yield loss in irrigated rice. Euphytica, 113:109-118, 2000.

BARBER, S.A. Soil nutrient bioavailability: A mechanistic approach. 2.ed. New York, John Wiley \& Sons, 1995. 414p.

BISSANI, C.A. \& ESCOSTEGUY, P.A.V. Estimativa de H+Al pelo pH SMP em solos do Rio Grande do Sul e de Santa Catarina. R. Bras. Ci. Solo, 23:175-179, 1999.

BOHM, W. Methods of studying root systems. New York, Springer-Verlag, 1979. 189p.

CARMONA, L.C.; PULVER, E. \& CARMONA, F.C. Fertilização antecipada como estratégia de manejo para altas produtividades. In: CONGRESSO BRASILEIRO DE ARROZ IRRIGADO, 4.; REUNIÃO DA CULTURA DO ARROZ IRRIGADO, 26., Santa Maria, 2005. Anais. Santa Maria, 2005. p.413-414.
CASTILLO, E.G.; TUONG, T.P.; ISMAIL, A.M. \& INUBUSHI, K. Response to salinity in rice: Comparative effects of osmotic and ionic stresses. Plant Prod. Sci., 10:159-160, 2007.

CHHABRA, R. \& ABROL, I.P. Reclaiming effect of rice grown in sodic soils. Soil Sci., 124:49-55, 1977.

CONAB. Disponível em:<http://www.conab.gov.br/conabweb/ download/safra/6lexafra.pdf>. Acesso em: 6 jul. 2007.

COUNCE, P.A.; KEISLING, T.C. \& MITCHELL, A. A uniform, objective, and adaptive system for expressing rice development. Crop Sci., 40:436-443, 2000.

COUNCE, P.A.; MOLDENHAUER, K.A.K. \& MARX, D.B. Rice yield and plant yield variability responses to equidistant spacing. Crop Sci., 29:175-179, 1989.

CRAMER, G.R.; EPSTEIN, E. \& LÄUCHLI, A. Effect of sodium, potassium and calcium on salt stressed barley. II. Elemental analysis. Physiol. Plant., 81:197-202, 1991.

CRAMER, G.R.; LAUCHLI, A. \& POLITO, V.S. Displacement of $\mathrm{Ca}^{2+}$ by $\mathrm{Na}^{+}$from plasmalemma of root cells: A primary response to stress? Plant Physiol., 79:207-211, 1985.

DING, Y.; LUO, W. \& XU, G. Characterization of magnesium nutrition and interaction of magnesium and potassium in rice. Ann. Appl. Biol., 149:111-123, 2006.

EHRLER, W. Some effects of salinity on rice. Bot. Gazette, 122:102-104, 1960.

GARCIA, A.; RIZZO, C.A.; UD-DIN, J.; BARTOS, S.L.; SENADHIRA, D.; FLOWERS, T.J. \& YEO, A.R. Sodium and potassium transport to the xylem are inherited independently in rice, and the mechanisms of sodium: Potassium selectivity differs between rice and wheat. Plant Cell Environ., 20:1167-1174, 1997.

GLENN, E, P.; BROWN, J.J. \& BLUMWALD, E. Salt tolerance and crop potential of halophytes. Crit. Rev. Plant Sci., 18:227-255, 1999

INSTITUTO DE PESQUISAS AGRONÔMICAS - IPAGRO. Atlas Agroclimático do Estado do Rio Grande do Sul. 1989. v.3.

IRGA. Disponível em: <http://www.irga.rs.gov.br/arquivos/ Sistemas_de_Cultivo.pdf $>$. Acesso em: 17 fev. 2008.

KAWASAKI, T.; AKIBA, T. \& MORITSUGU, M. Effects of high concentrations of sodium chloride and polyethilene glycol on the growth and ion absorption in plants. I. Water culture experiments in a greenhouse. Plant Soil, 75:75$85,1983$.

LOPES, S.I.G.; VOLKWEISS, S.J. \& TEDESCO, M.J. Desenvolvimento do sistema radicular do arroz irrigado. R. Bras. Ci. Solo, 18:273-278, 1994.

McNEAL, B.L.; PEARSON, G.A. \& BOWER, C.A. Effect of rice culture on the reclamation of sodic soils. Agron. J., 58:238-240, 1966. 
MACHADO, M.O. \& TERRES, A.L. Tolerância de genótipos à salinidade do solo - safra 1994/1995. In: REUNIÃO DA CULTURA DO ARROZ IRRIGADO, 21., Porto Alegre, 1995. Anais. Porto Alegre, Instituto Rio Grandense do Arroz, 1995. p.48-50.

MARCOLIN, E.; ANGHINONI, I.; MACEDO, V.M.; GENRO JUNIOR, S.A. \& VEZZANI, F.M. Salinidade da cultura do arroz no Rio Grande do Sul. R. Lavoura Arroz., 53:27-38, 2005.

MARCOLIN, E. \& MACEDO, V.R.M. Cultivares de arroz e a salinidade da água de irrigação. In: CONGRESSO BRASILEIRO DE ARROZ IRRIGADO, 2.; REUNIÃO DA CULTURA DO ARROZ IRRIGADO, 24., Porto Alegre, 2001. Anais. Porto Alegre, Instituto Rio Grandense do Arroz, 2001. p.229-231.

MARIOT, C.H.P.; MENEZES, V.G.; LIMA, A.L.; RAMIREZ, H.V. \& NEVES, G. Influência da época de semeadura no rendimento de grãos de cultivares de arroz irrigado. In: CONGRESSO BRASILEIRO DE ARROZ IRRIGADO, 4.; REUNIÃO DA CULTURA DO ARROZ IRRIGADO, 26. Santa Maria, 2005. Anais. Santa Maria, 2005. p.251-253.

MELO, P.C.S.; ANUNCIAÇÃO FILHO, C.J.; OLIVEIRA, F.J.; BASTOS, G.Q.; TABOSA, J.N.; SANTOS, V.F. \& MELO, M.R.C.S. Seleção de genótipos de arroz tolerantes a salinidade durante a fase vegetativa. Ci. Rural, 36:58-64, 2006.

OBATA, T.; KITAMOTO, H.K.; NAKAMURA, A.; FUKUDA, A. \& TANAKA, Y. Rice shaker potassium channel OsKAT1 confers tolerance to salinity stress on yeast and rice cells. Plant Physiol., 144:1978-1985, 2007.

OSTER, J.D.; HOFFMAN, G.J. \& ROBINSON, F.E. Management alternatives: Crop, water and soil. California Agric., 36:29-32, 1984
SANTOS, M.F.G.; OLIVEIRA, F.A.; CAVALCANTE, L.F.; MEDEIROS, J.F. \& SOUZA, C.C. Solo sódico tratado com gesso agrícola, composto de lixo urbano e vinhaça. R. Bras. Eng. Agric. Amb., 9:307-313, 2005.

SOCIEDADE BRASILEIRA DE ARROZ IRRIGADO - SOSBAI. Recomendações técnicas da pesquisa para o Sul do Brasil. Pelotas, 2007. 161p.

STULP, V.; MATUELA, J.; CARMONA, L. \& FERRUGEM, G. Dimensionamento econômico de tratores para a lavoura de arroz irrigado. R. Econ. Sociol. Rural, 35:45-61, 1997.

SULTANA, N.; IKEDA, T. \& ITOH, R. Effect of NaCl salinity on photosynthesis and dry matter accumulation in developing rice grains. Environ. Exper. Bot., 42:211-220, 1999.

TAIZ, L. \& ZEIGER, E. Plant physiology. 3.ed. Sunderland, Sinauer Associates, 2002. 798p.

TEDESCO, J.M.; GIANELLO, C.; BISSANI, C.A.; BOHNEN, H. \& VOLKWEISS, S.J. Análise de solo, plantas e outros materiais. 2.ed. Porto Alegre, Universidade Federal do Rio Grande do Sul, 1995. 174p. (Boletim Técnico de Solos, $5)$.

TESTER, M. \& DAVENPORT, R. $\mathrm{Na}^{+}$tolerance and $\mathrm{Na}^{+}$ transport in higher plants. Ann. Bot., 91:503-527, 2003.

TURNER, F.T. \& McCAULEY, G.N. Rice. In: TEAVE, J.D. \& PEAT, M.M., eds. Crop water relations. New York, J. Wiley, 1983. 547p.

WELFARE, K.; FLOWERS, T.J.; TAYLOR, G. \& YEO, R. Additive and antagonistic effects of ozone and salinity on the growth, ion contents and gas exchange of five varieties of rice (Oryza sativa L.) Environ. Pollut., 92:257-256, 1996. 